\title{
WELDING ANALYSIS OF GRAY CAST IRON ASTM A48 CLASS 40 USING SMAW
}

\author{
Diah Kusuma Pratiwi ${ }^{*}$, Amir Arifin ${ }^{1}$, \\ REZA ANDRE SUHADA ${ }^{2}$ \\ ${ }^{I}$ Dept. of Mechanical Engineering, Faculty of Engineering, Universitas Sriwijaya, Indralaya, South \\ Sumatera, Indonesia \\ *Corresponding author: pratiwidiahkusuma@ft.unsri.ac.id
}

(Received: 21 August 2021; Accepted: 22 September 2021; Published on-line: 1 November 2021)

\begin{abstract}
The mechanical and physical characteristics of gray cast iron are intricately bound to its application as an essential material in manufacturing various goods. SMAW (Shielded Metal Arc Welding) is the most simple and widely used electric arc welding method. In this work, ASTM A48 gray cast iron Class 40 was joining using the SMAW method with the welding position used was $1 \mathrm{G}$ or underhand position. The joining used is the Butt Joint using an open Singel V seam with a current of 120A. The joining of Welding was characterized through dye penetrant and hardness tests. Rockwell hardness tests on base metal and heat affected zone reveal that the heat affected zone has the highest hardness value of 56.5 HRC, while the base metal has the lowest hardness value (41 HRC). Graphite, pearlite, and pearlite were all visible in the microstructure study.
\end{abstract}

KEY WORDS: SMAW Welding, Gray Cast Iron, Hardness

\section{INTRODUCTION}

Welding is a metallurgical bond at the joining of a metal or metal alloy carried out in a molten or liquid condition, according to the definition of the Deutsche Industrie Normen (DIN). As defined by this definition, Welding is the use of heat energy to form a local connection between multiple metal rods. Currently, more than 40 types have been used, including Welding, which is done by simply pressing two metals that are joined so that bonds occur between atoms or molecules of the metal being joined.

Shielded Metal Arc Welding (SMAW) or electrode shielded arc welding is a welding method that employs an electric arc to melt metal [1,2]. An electric arc is formed between the shielded electrode and the base metal. The base metal and the tip of the electrode melt will solidify simultaneously because of the heat from the electric arc [3]. The base metal in this Welding undergoes melting due to heating from an electric arc that arises between the electrode tip and the workpiece surface [4]. The electrode used is a wire wrapped with a protective flux. These electrodes during the welding process will experience melting together with the parent metal and solidify together to become part of the weld seam [5].

Gray cast iron is the most common type of cast iron because of its good vibration damping and self-lubrication properties [6]. The graphite in gray cast iron in the form of a flake is formed upon freezing. Gray cast iron graphite is flake-shaped in the form of small, curved plates. The edges of the graphite are pointed, which results in the low toughness of gray cast iron. Gray cast iron has a relatively high silicon content, between 1-3\%, carbon content between $2.5-4.0 \%$, and manganese content between $0.2-1.0 \%$. While the phosphorus content is between $0.002-$ 
$1.0 \%$, and sulfur is between $0.020 .025 \%$. The microstructure of grey cast iron, as shown in Fig 1.

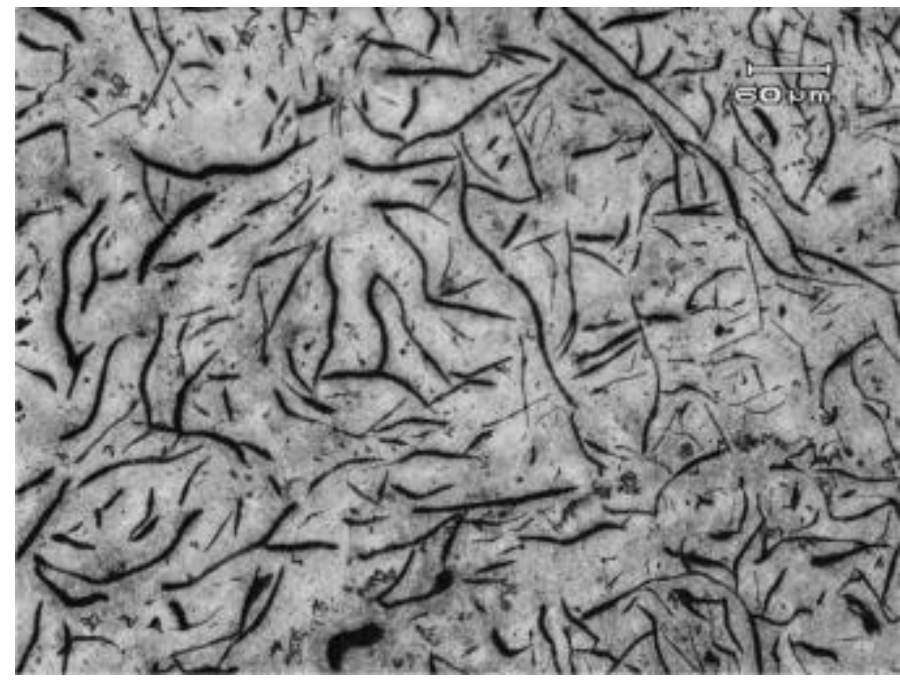

Fig. 1. The microstructure grey cast iron [7]

One of the welding processes performed on cast iron is Shielded Metal Arc Welding (SMAW). The most likely result of the cast iron welding process is weld cracks caused by freezing that occurs too quickly; shrinkage stress is too high, welding procedures that are not suitable, and the use of inappropriate electrodes. The objective of this work is to analyses the process and results of physical properties and mechanical properties of the welding gray cast iron using SMAW

\section{METHODOLOGY}

Shielded Metal Arc Welding (SMAW) welding process is carried out using electric energy (AC/DC). ASTM A48 Class 40 gray cast iron was joining using Lincoln Inventer v275 SMAW welding machine. The welding specimen was machining with dimensions of $140 \mathrm{~mm} \times 60 \mathrm{~mm}$ with a plate thickness of $10 \mathrm{~mm}$. The welding position used is $1 \mathrm{G}$ during the welding process. The Butt Joint type is utilized with an open Single V seam, as shown in Fig. 2, and the current user is 120A. ENi-Cl was chosen as filler with the composition as seen in Table 1. PMIMASTER PRO was utilized to analyse the composition of raw materials. An inspection using Dye penetrant inspection is carried out to analyse the quality of the weld.

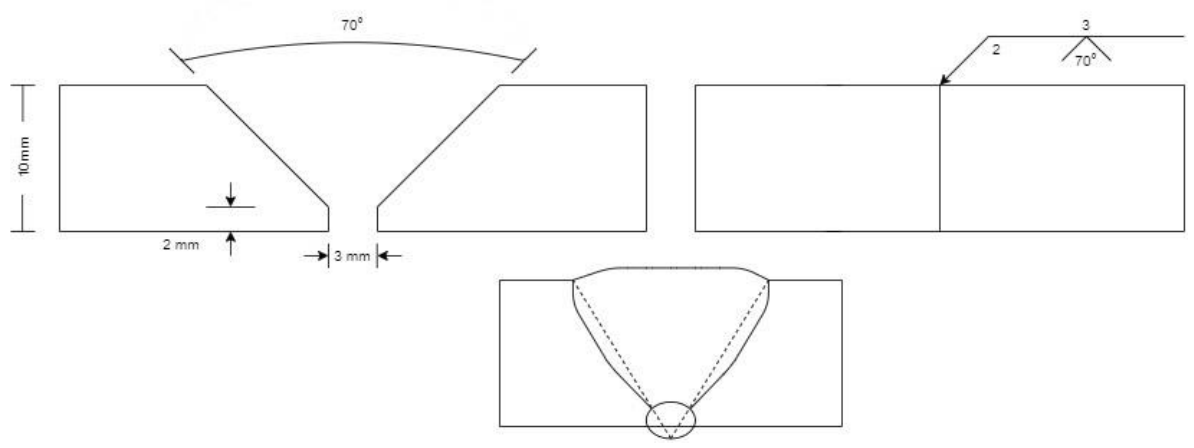

Fig 2. Butt Joint type used during the welding process 
Table 1: Welding electrode composition

\begin{tabular}{cccccccc}
\hline Element & $\mathrm{Fe}$ & $\mathrm{Mn}$ & $\mathrm{Si}$ & $\mathrm{Ni}$ & $\mathrm{C}$ & $\mathrm{P}$ & $\mathrm{S}$ \\
\hline wt\% & 8.0 & 2.5 & 4 & $\mathrm{Re}$ & 1.95 & 0.01 & 0.03 \\
\hline
\end{tabular}

Table 2. gray cast iron composition ASTM A48

\begin{tabular}{ccccccccccc}
\hline Element & $\mathrm{Fe}$ & $\mathrm{Ce}$ & $\mathrm{Mn}$ & $\mathrm{Ni}$ & $\mathrm{C}$ & $\mathrm{Mo}$ & $\mathrm{Mg}$ & $\mathrm{P}$ & $\mathrm{S}$ \\
\hline $\mathbf{w t \%}$ & $\mathrm{Re}$ & 0.45 & 0.61 & 1.58 & 3.34 & 0.11 & 0.05 & 0.1 & 0.09 \\
\hline
\end{tabular}

\section{RESULTS AND DISCUSSION}

ASTM A48 Class 40 gray cast iron has been successfully joined using the Shielded Metal Arc Welding (SMAW) Method, as shown in Fig 3.

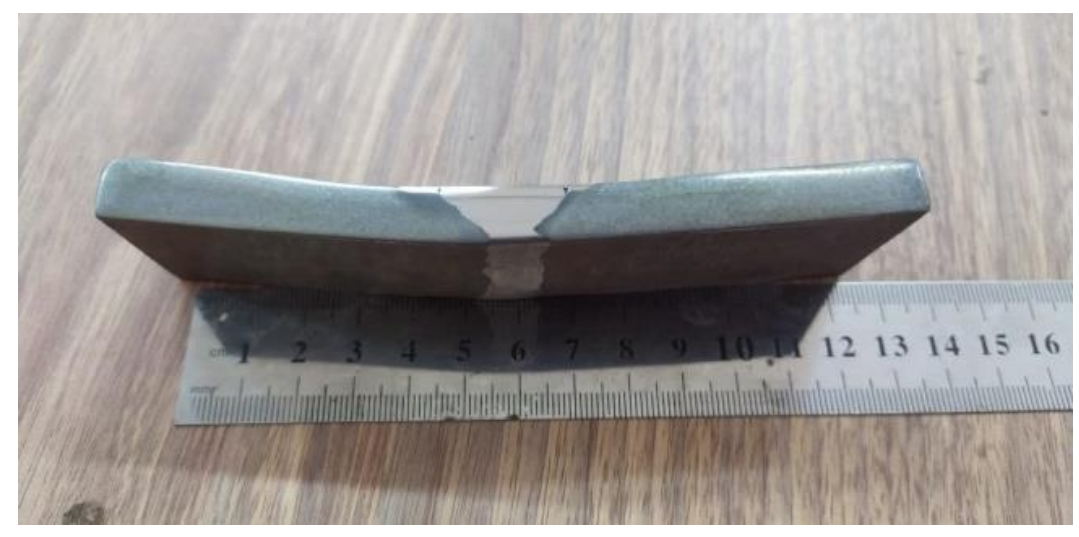

Fig. 3. Photographic view of the welded sample.

The composition results revealed that ASTM A48 Class 40 gray cast iron has a carbon composition is $3.34 \mathrm{wt} \%$, as shown in Table 2. ASTM A48 No. 40 is a middle grade of gray cast iron in the USA, and there is no equivalent grade for other countries.

ASTM A48 Class 40 gray cast iron that has been welded is checked using Dye penetrant inspection to investigate the quality of the welds produced. Dye penetrant inspection is a lowcost, extensively used inspection technology for checking surface-breaking flaws in all nonporous materials (metals, plastics, or ceramics). The penetrant may be used on both non-ferrous and ferrous materials. However, magnetic particle inspection is frequently employed for ferrous components because of its subsurface detection capacity.

The results of the dye penetrant inspection revealed that various faults, including porosity, splatter, and crack, had been discovered (Fig. 4.a-b). Welding defects can generate stress concentrations in the welding area, which can result in the formation of early cracks in the weld joint. Defects during the welding process can be caused by a variety of factors, including welding conditions and the welder's abilities. 


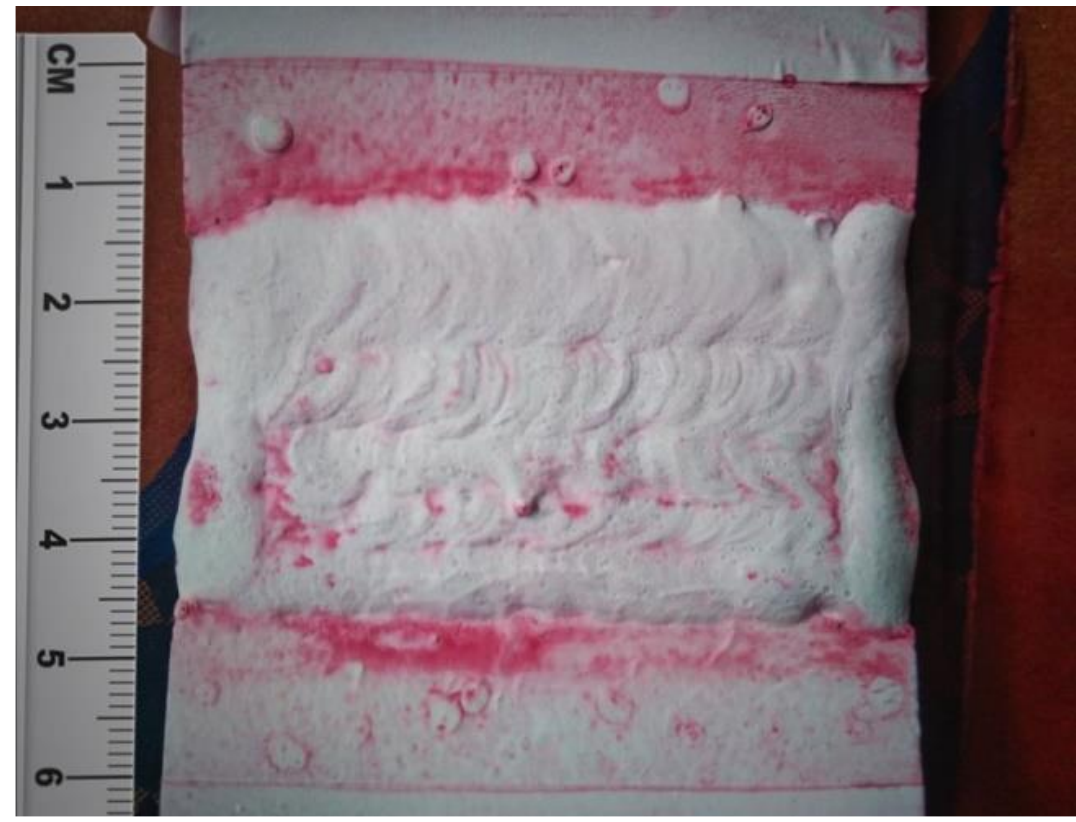

(a)

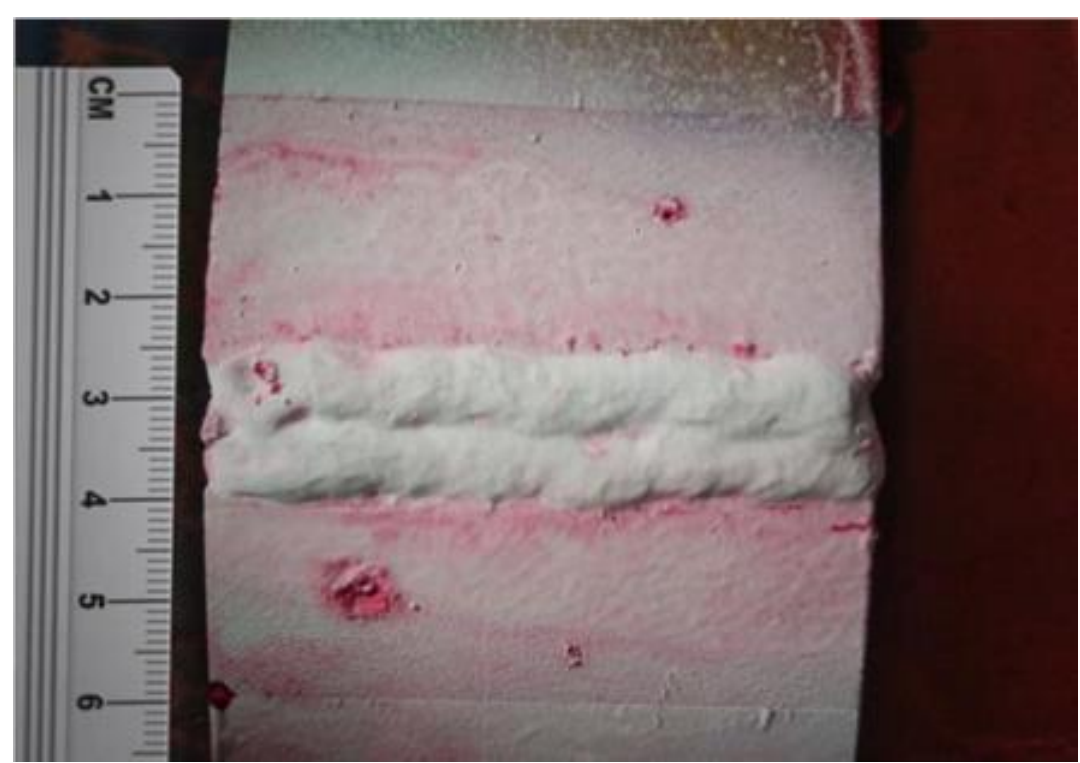

(b)

Fig. 4. Morphology of dye penetrant result on the root pass

A microstructure analysis procedure was performed to investigate the base metal area and heat affected zone. The polished specimen was etched using $3 \mathrm{~mL}$ of Nital (HNO) and $97 \mathrm{~mL}$ of alcohol. The microstructure of ASTM A48 Class 40 gray cast iron base metal and HAZ area can be seen in Fig. 5.a-b. An enlargement of the grain boundaries in the HAZ region because of the heat exposure during the welding process $[5,8]$. Moreover, some phases observed, such as graphite, ferrite, and pearlite, are visible in the base metal and HAZ areas [9]. 


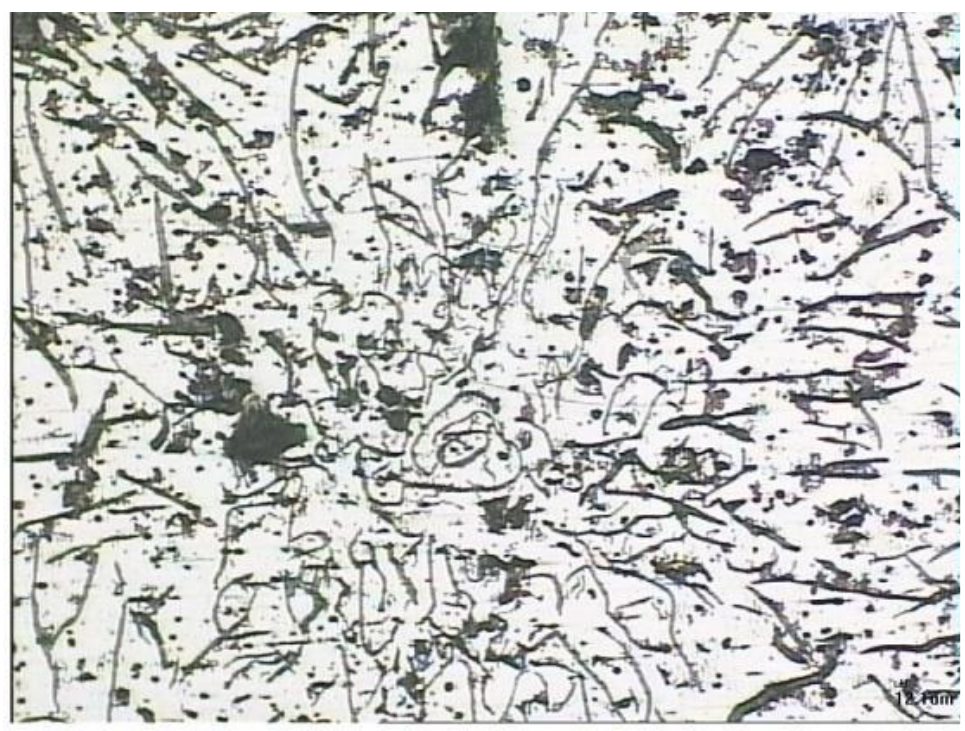

(a)

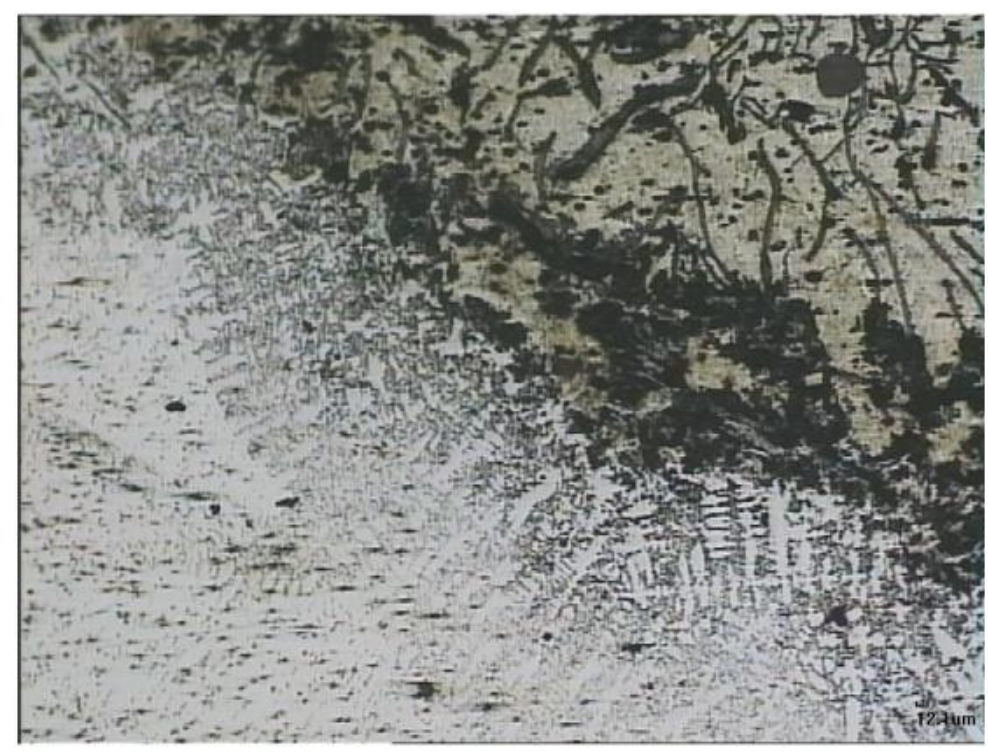

(b)

Fig 5. Micrographs showing the microstructure at the a) ASTM A48 Class 40 gray cast iron base metal, b) HAZ area ASTM A48 Class 40 gray cast iron.

To investigate the hardness profile of the weld joint. Rockwell hardness testing is carried out in the Lab. Materials Engineering Department of Mechanical Engineering Sriwijaya University. The weld joint's highest hardness value was obtained on heat affected zone (56.5 HRC) [10-12]. The result Hardness profile of the weld joint can show in Fig. 6. 


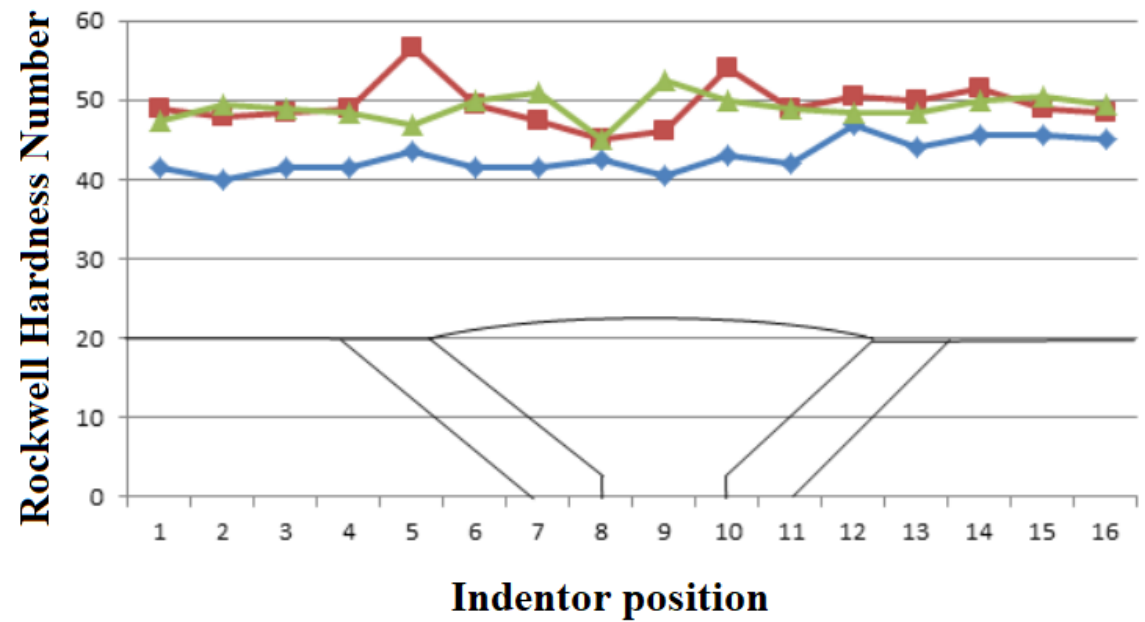

Fig. 6. Rockwell hardness profile of ASTM A48 Class 40 gray cast iron measured along the centerline of the cross-section.

\section{CONCLUSION}

ASTM A48 Class 40 gray cast iron has been welded using Shielded Metal Arc Welding. Several defects were observed on the weld joint based on dye penetrant results, such as porosity, crack, and spatter. Rockwell hardness test on base metal and heat affected zone shows that the heat affected zone area has the highest hardness value of $56.5 \mathrm{HRC}$. The weld metal is affected by the heat generated during welding and alloys composition from the filler. The lowest hardness value is in the base metal area (41 HRC). Microstructure analysis revealed some graphite, pearlite, and pearlite have been observed clearly.

\section{REFERENCES}

[1] A. Arifin et al., "Optimization of Angular Distortion on Weld Joints Using Taguchi Approach," Jurnal Kejuruteraan, vol. 31, 2019:.

[2] D. Pathak, R. P. Singh, S. Gaur, and V. Balu, "Influence of input process parameters on weld bead width of shielded metal arc welded joints for AISI 1010 plates," Materials Today: Proceedings, vol. 38, pp. 24-28, 2021.

[3] L. Jeffus, Welding: Principles and Applications. Cengage Learning, 2016.

[4] Afriansyah and A. Arifin, "Dissimilar metal welding using Shielded metal arc welding: A Review," Technology Reports of Kansai University, vol. 62, no. 04, 2020.

[5] S. Kou, Welding Metallurgy. John Wiley \& Sons, Inc, 2003.

[6] J. Keller, V. Fridrici, P. Kapsa, S. Vidaller, and J. F. Huard, "Influence of chemical composition and microstructure of gray cast iron on wear of heavy duty diesel engines cylinder liners," Wear, vol. 263, no. 7-12, pp. 1158-1164, 2007.

[7] E. E. T. Elsawy, M. R. El-Hebeary, and I. S. E. El Mahallawi, "Effect of manganese, silicon and chromium additions on microstructure and wear characteristics of grey cast iron for sugar industries applications," Wear, vol. 390-391, pp. 113-124, 2017.

[8] S. American Welding and A. L. Phillips, Welding handbook (Welding Handbook). American Welding Society, 1957.

[9] K.-E. Thelning, Steel and Its Heat Treatment. Butterworth Heinemann, 2000.

[10] R. K. Buddu, N. Chauhan, and P. M. Raole, "Mechanical properties and microstructural investigations of TIG welded $40 \mathrm{~mm}$ and $60 \mathrm{~mm}$ thick SS 316L samples for fusion reactor vacuum vessel applications," Fusion Engineering and Design, vol. 89, no. 12, pp. 3149-3158, 2014. 
[11] Y. Kchaou, N. Haddar, G. Hénaff, V. Pelosin, and K. Elleuch, "Microstructural, compositional and mechanical investigation of Shielded Metal Arc Welding (SMAW) welded superaustenitic UNS N08028 (Alloy 28) stainless steel," Materials \& Design, vol. 63, pp. 278-285, 2014.

[12] D. Pathak, R. P. Singh, S. Gaur, and V. Balu, "Influence of groove angle on hardness and reinforcement height of shielded metal arc welded joints for low carbon AISI 1016 steel plates," Materials Today: Proceedings, vol. 38, pp. 40-43, 2021. 